\title{
A Review on COVID-19 Diagnosis Tests Approved for Use in Brazil and the Impact on Pandemic Control
}

\author{
Jean Michel Dela Vedova-Costa ${ }^{1}$ \\ https://orcid.org/0000-0002-5656-7239 \\ Eliézer Lucas Pires Ramos ${ }^{1}$ \\ https://orcid.org/0000-0002-9437-5545
}

\section{Raphael Aparecido Boschero 1 \\ https://orcid.org/0000-0002-9668-7526}

Gabriela Nascimento Ferreira ${ }^{1}$

https://orcid.org/0000-0003-4313-479X

\section{Vanete Thomaz Soccol ${ }^{1 *}$ \\ https://orcid.org/0000-0001-9301-541X}

\author{
Manuel Hospinal Santiani ${ }^{1}$ \\ https://orcid.org/0000-0002-4775-9415 \\ Violetta Dias Pacce ${ }^{1}$ \\ https://orcid.org/0000-0003-1576-5949
}

\author{
Bruno Paulo Rodrigues Lustosa ${ }^{2}$ \\ https://orcid.org/0000-0002-0150-5962 \\ Vânia Aparecida Vicente ${ }^{2}$ \\ https://orcid.org/0000-0002-2953-4861
}

\section{Carlos Ricardo Soccol ${ }^{1}$ \\ https://orcid.org/0000-0001-7630-6864}

${ }^{1}$ Federal University of Paraná, Laboratory of Molecular Biology, Bioprocess Engineering and Biotechnology Department; Curitiba, Paraná, Brazil. ${ }^{2}$ Federal University of Parana, Basic Pathology Department, Curitiba, Paraná, Brazil.

Editor-in-Chief: Alexandre Rasi Aoki

Associate Editor: Bruno Pedroso

Received: 2021.03.10; Accepted: 2021.05.07.

*Correspondence: soccol@ufpr.br; Tel.: +55-41-33613555 (C.R.S.).

\section{HIGHLIGHTS}

- The main COVID-19 diagnostic methods in Brazil are updated.

- More than $80 \%$ of the approved products are from other countries.

- The tests are based on the detection of nucleic-acid (15.8\%), antigen (13\%) and antibody (71.2\%).

- The most of Brazilian federative units show an elevated percentage of cases per samples tested.

Abstract: With the COVID-19 pandemic, many diagnostic tests (molecular or immunological) were rapidly standardised, given the urgency of the situation, many are still in the process of being validated. The main objective of this study was to review the aspects of the diagnostic kits approved in Brazil and their application in the different federative units to gather epidemiological information. In order to achieve these objectives, a survey was carried out on the data available at the regulatory agency (ANVISA) and in the literature. The main countries that have registered products in Brazil are China (51.4\%), Brazil (16.6\%), South Korea $(9.2 \%)$, USA $(8.8 \%)$ and Germany $(3.6 \%)$. The methodologies of these products are based on the detection of nucleic-acid (15.8\%), antigen (13\%) and antibody (71.2\%). In the immunological tests, it was verified that the sensitivity ranged from 55 to $100 \%$ and the specificity from 80 to $100 \%$. The percentage of cases in the samples tested in Brazil is elevated in almost all federative units since eight states showed $40 \%$ of positive cases in tested samples, while 18 states displayed between 20 and $40 \%$. In conclusion, this review showed 
that Brazil is dependent on external technology to respond to pandemics, epidemics and endemics disease and needs to improve its biotechnological scheme to solve further diseases outbreaks.

Keywords: SARS-CoV-2; COVID-19; diagnosis; nucleic-acid-based test; immunological test; RT-qPCR; immunochromatography; ELISA; Brazil.

\section{INTRODUCTION}

COVID-19 is caused by the severe acute respiratory syndrome coronavirus 2 (SARS-CoV-2), which is believed to have emerged from Wuhan city, Hubei province, China, in December 2019 [1]. The disease spread quickly through China and other countries, raising global concern [2], and in March $11^{\text {th }}, 2020$ it was declared a pandemic by the World Health Organization (WHO) [3]. Back at that time, the disease had 149,313 confirmed cases and 4,635 deaths. Nowadays, it has reached over 108.5 million of cases and 2.4 million deaths globally [4]. In Brazil, 9.7 million cases and 236,397 deaths were reported until February $8^{\text {th }}$. Moreover, the social impact of the pandemic outbreak was spilled to every section from agriculture and manufacturing industry to education, and primarily, healthcare systems worldwide [5].

SARS-CoV-2 is a virus that belongs to group 2 of Betacoronavirus genus, Coronaviridae family [6]. Viruses from this family contain a single-strand RNA genome that varies from 26 to 32 kilobases $(\mathrm{kb})$ and share similarities of expression. They also have 16 nonstructural proteins encoded by ORF 1ab at 5' end, followed by four structural proteins: Spike (S), Envelope (E), Membrane (M) and Nucleocapsid (N) encoded by ORFs at the 3' end [7]. Isolation and sequencing of the SARS-CoV-2 strain made possible to study the genomics and proteomics, and also analyze its zoonotic origin [8]. All these proteins cited above have similarities (90.4-100\%) with the amino acid identity of a coronavirus strain isolated from the Malayan pangolin (Manis javanica), suggesting the animal was an intermediate host of the virus, and that SARS-CoV2 emerged from a possible recombination between viruses of bat and pangolin $[1,9]$.

In the process of infection, the virus binds itself through the receptor-binding domain (RBD) from Spike protein in its cognate receptor, the angiotensin-converting enzyme 2 (ACE2). A successful entry depends on the effectiveness of cleavage by the transmembrane protease and/or fusion of virus-cell membrane by endolysosomal cathepsin L [10]such as previous SARS-CoV virus. However, the latter displays a mutation on RBD that was correlated with a higher binding affinity and possibly increased infectivity [11,12]. Due to high expression of ACE2, alveolar macrophages, vascular endothelial and alveolar epithelial cells are the first target cells of SARS-CoV-2 that leads in an early infection and subsequent replication [10,13]. Moreover, other mutations on the worldwide isolated strain seems to be associated with an increased human-to-human transmission efficiency $[14,15]$.

Transmission of virus is mainly through respiratory droplets when in a close contact with infected individual, but can also happen by aerosol in longer distances and direct contact with contaminated surfaces $[16,17]$. It was reported that genetics can influence on how each immune system will respond to the infection, which varies individually. This may explain why some people develop severe symptoms and others are asymptomatic $[18,19]$. Symptoms starts in two to 14 days after exposure and they manifest mostly as flu-like symptoms, such as fever, cough and dyspnea [20]. Other less common features are sore throat, runny nose, sneezing and diarrhea [21]. However, it can also progress to more severe states as acute respiratory distress (ARDS), pneumonia, renal failure and death [22,23].

According to the Western democracies, World Health Organization (WHO) and the Centers for Disease Control and Prevention (CDC), there are several points to take into consideration when looking for strategies to control and avoid the spread of viruses in a pandemic, one of them is "Test quickly, virgorously and widely" [18]. Therefore, in order to manage a severe pandemic outbreak, an accurate diagnostic is of significant importance. This article shows a review and discussion about the diagnostic tests applied for the detection of SARS-CoV-2 in Brazil approved by the Brazilian National Health Surveillance Agency (ANVISA), as well as the current researches on novel and/or improved methodologies. In addition, an epidemiological analysis of COVID-19 cases and with the number of tests applied in the brazilian federative are analysed.

\section{DIAGNOSTIC TEST}

Initially, the ANVISA published in March $17^{\text {th }}, 2020$ a temporarily resolution with the registration for approved use of diagnostic kits due to the public health SARS-CoV-2 emergency [24]. In this resolution, the maximum analysis time of an application would be 30 days. However, it was also clearly exposed that the absence of any performance study or data restriction should be justified by technical motivations, which 
allowed the assessment of reliability of the results and the diagnostic effectiveness of the product [25]. Some of the other changes that concern the emergency approval are: all registers considered in this regulation need validation for 1 year; during this validation time, it is still requiring to companies to present additional information regarding the regular aspects for registration. It is also required that final product labelling presents "Approved for emergency use" until the completion of all regular aspects [24].

Previous ANVISA resolution from 2015 regarding the approval of diagnostic tests explicitly prohibits the use of the serological tests to the diagnosis of infectious diseases and of compulsory notification in form of auto-testing. However, in another temporarily measure from April 2020, ANVISA decided to release the sale of rapid tests in pharmacies without the necessity of a medical professional, whether for a clinical evaluation of the individual case and the need for the test, or for the technical responsibility and guarantee of the laboratory examination quality. ANVISA's role with the new regulations is to promote the protection of the population health facing COVID-19 by speeding up the bureaucratic processes on approval and commercialization of the diagnostic tests [26].

At the date of February $8^{\text {th }}, 2021$, ANVISA has approved 508 diagnostic tests, while 132 are pending approval and 130 not approved [27]. From the approved tests, eight were control samples for serologic tests. The remaining 500 submissions can be classified as nucleic-acid-based test, antigen detecting test and antibodies detecting test [28]. Along the first year of pandemic, there was a high volume of accepted submissions from March 2020 to July 2020, most of them being from serological tests. Submissions requiring for lateral-flow tests to the detection of antigens exhibited an increase during the last four months (Figure 1a). Moreover, tests manufactured in China accounted for half (51.4\%) of the accepted tests (Figure 1b), followed by those from Brazil (16.6\%), South Korea (9.2\%), USA (8.8\%) and Germany (3.6\%). This disparity of manufacturing products and inputs that has to import from other countries rather than a national fabrication. Probably, this difference is explained by the relatively low funding for research, development and innovation projects, which ends up leaving the country dependent on the international market [29].

As previously mentioned, COVID-19 can be diagnosed directly through the detection of the SARS-CoV2 nuclei acid or proteins (detection of antigen) presents on a clinical sample, and also indirectly by the identification of host defense molecules, like the antibodies [30]. Real-time PCR (qPCR) is an example of a molecular test that detects RNA of the virus. Lateral-flow or immunochromatography can detect antigens or antibodies, as well as the Enzyme-Linked Immunosorbent Assay (ELISA). The immunochromatography technique is the most solicited method to an approval (Figure 1c) possibly due to its being a rapid, simple, sensible and importantly, a point-of-care test [31,32]. All these assays and its mechanisms will be further discussed along this review.

\subsection{NUCLEIC-ACID-BASED TESTS}

The detection of viral RNA is the most reliable way to verify current SARS-CoV-2infection . The main nucleic-acid-based technique is One step quantitative reverse transcription polymerase chain reaction (RTqPCR), which is the gold standard for COVID-19 diagnosis [33,34]. The method consist in combining two molecular reactions at "one step" procedure: reverse transcription of viral RNA into cDNA and further amplification of specific cDNA targets by PCR [35]. The viral RNA in the nasopharyngeal swab becomes detectable from the first day and peaks within the first week of symptom onset. The detection starts to decrease in the third week [36].

Almost all nucleic-acid-based tests approved by ANVISA for COVID-19 diagnosis are RT-qPCR what represent $15.6 \%(78 / 500)$ of all tests (Figure 1c). The main differences between them are the target genes of SARS-CoV-2 and the amount of target genes are used. Gene N and ORF1ab are the mainly targets and constitute $70.7 \%(53 / 75)$ and $50.7 \%$ (38/75) of the tests, respectively (Figure 2). According to the literature, the gene E, N and ORF 1ab are the priority targets for the most assays [37]. Also, CDC and World Health Organization (WHO) guidelines for molecular COVID-19 diagnosis indicates that a positive RT-qPCR need to have at least two target genes detected for a confirmed positive diagnostic [38]. Thus, most of the molecular tests accepted by ANVISA target more than one gene (Figure 2). 


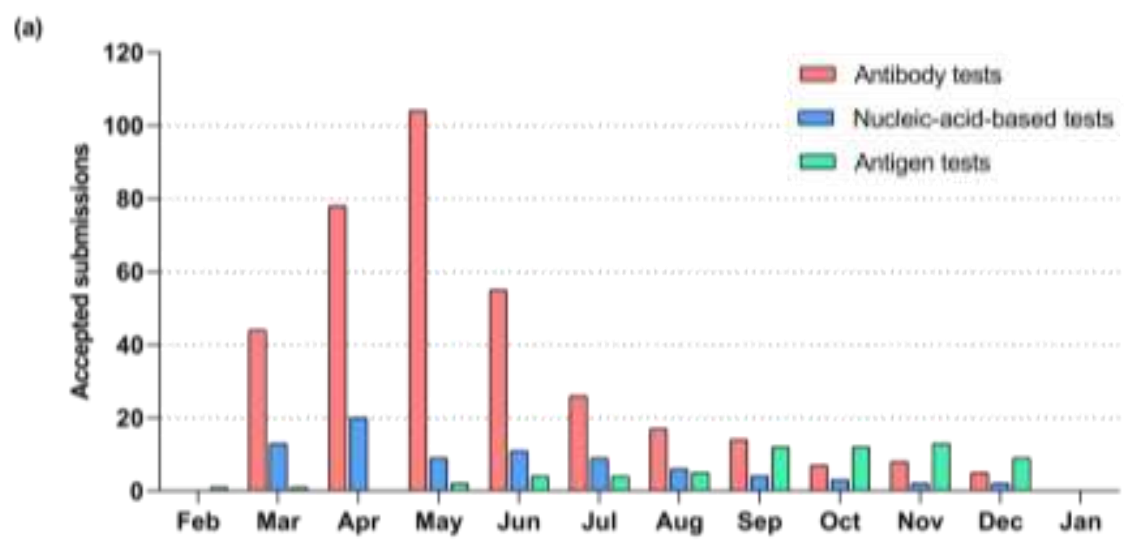

(b)

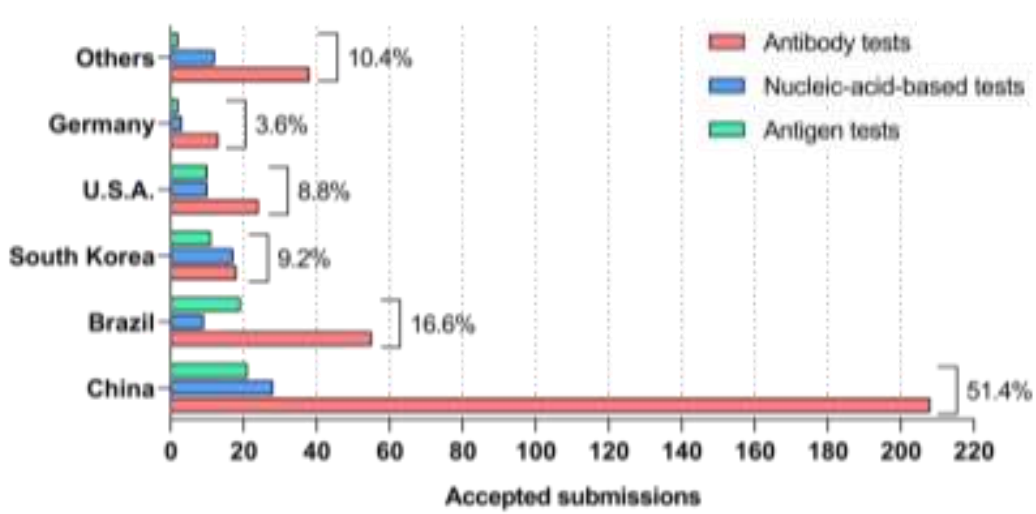

(c)

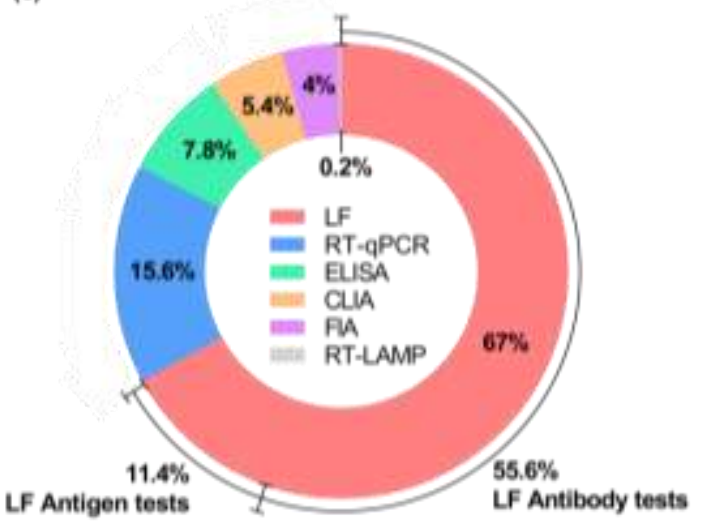

Figure 1. Total of 500 accepted submissions of COVID-19 diagnosis tests submitted to the ANVISA, regulatory agency. Distribution of submissions (a) over the year of 2020 and 2021; (b) by country of origin accordingly to the test target: nucleic-acid-based, antigen or antibody; (c) by platform: lateral flow immunoassay (LF); quantitative reverse transcription polymerase chain reaction (RT-qPCR); enzyme-linked immunosorbent assay (ELISA); chemiluminescent immunoassay (CLIA); fluorescent immunoassays (FIA); and reverse transcription loop-mediated isothermal amplification (RT-LAMP) [27].

In the beginning of COVID-19 pandemic the absence of large SARS-CoV-2 genomes datasets created the need of using phylogenetic analysis from the Sarbecovirus clade to rapidly develop specific SARS-CoV2 primers and probes [37,39]. The Sarbecovirus subgenus are several coronavirus isolated from bats and includes the human SARS-CoV virus, responsible agent of SARS disease in 2002 [40]. In this context, the phylogenetic analysis reveals that SARS-CoV-2 virus has more than $85 \%$ of genome similarity with bat coronavirus previously isolated from this clade [41]. The SARS-CoV-2 primers are able to detect RNA from this virus clade, since they were mostly isolated from non-human samples. Additionally, the primers do not detect any other human respiratory virus ensuring broad sensitivity and specificity in cases of acquisitions of SARS-CoV-2 variants [33].

Nucleic-acid-based diagnosis demands well equipped laboratories and thoroughly qualified personnel, what result in an elevated costs to perform a massive number of diagnosis per day [19]. Given these difficulties, some laboratories adopted the pool strategy to reduce number of COVID-19 tests, increasing their diagnosis capacity [42,43]. Thereby, when the frequency of positive results is $10 \%$ or less a pool of five samples can maintain the efficacy of RNA detection compared to individual detection [43-45]. Moreover, RTqPCR allows specific detection of the SARS-CoV-2 virus in a great variety of samples such as upper and down respiratory tract samples [46], fecal and anal swab samples [21], bronchoalveolar samples [46], surface and aerosol samples [47], and wastewater samples [48]. However samples for nucleic-acid-based tests must be carefully collected, transported and stored, because a minimal amount of RNA is required for the assays to be able to get a positive result, and also due to RNA instability [49]. Finally, RT-qPCR results allow rapid isolation of infected individuals and provide data that guide sanitary authorities on their decisions [50]. 


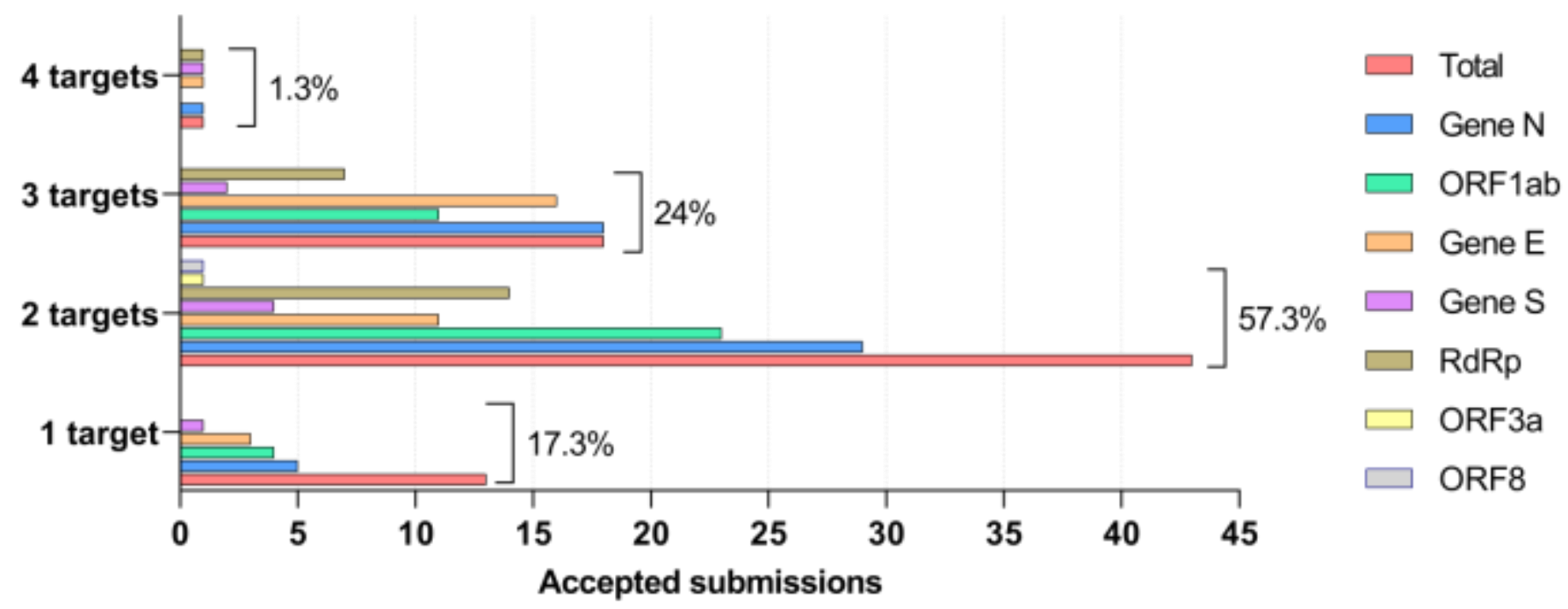

Figure 2. Classification of 75 nucleic-acid-based tests approved for use in Brazil. Tests are classified on the target region and number of targets. Data is provided by manufactures. Three manufactures did not provide information about the target region [27].

\subsection{IMMUNOLOGICAL TESTS}

Immunological tests make use of the antigen-antibody interaction to detect both virus-specific antigens and antibodies against viruses. Compared to tests for detection of nucleic acids, they are cheaper, faster and used as point-of-care devices [28]. In addition, they can be applied to diagnose initial phase of viral infection or past infection, promoting a better understanding of the transmission dynamics. For these reasons, immunological tests are a very suitable alternative for mass testing, and are essential for pandemic control [51]. Hence, the demand for these tests is high since COVID-19 appearance, corresponding to $84.2 \%$ $(421 / 500)$ of the tests approved for use in Brazil [27].

\subsubsection{Antigen tests}

Viral proteins are produced during the replication of SARS-CoV-2, and might serve as reporters for an ongoing infection. Tests targeting viral antigens can identify an active infection in highly specific way, similarly as nucleic-acid-based tests. They present some advantages, mainly related to their practicality and cost, and also have some disadvantages, like suboptimal sensitivity and the need for a sample with sufficient viral load [38]. Thus, these tests are very relevant on the pandemic context, and represent $13 \%(65 / 500)$ of the tests approved for use in Brazil (Figure 1c). The numbers of requests were lower on the beginning of COVID-19 pandemic and higher over time. With the new information available about the virus, there was an increase in the number of antigen approved tests (Figure 1b). The main reason might be related to high demand for tests, and the possibility to substitute nucleic-acid-based tests with a lower cost assay.

Clinical samples are mainly nasal and nasopharyngeal swab, and follow the same protocols for collection, storage and transportation as the ones for nucleic-acid-based tests. First, the person should tilt its head back, and a swab is inserted into the nostrils until reaching the nasopharyngeal region. Then the sample is collected by gently rotating the swab. This process is crucial because the detection of viral antigen requires a minimal antigen load on the samples [52].

Once the collection is finished, the swab is incubated with running buffer what allows the formation of the immune complex. The running buffer contains a stabilizer solution, labeled monoclonal antibodies against the target antigen, and antibodies for test control $[49,53]$. The antibodies are specific against the $\mathrm{S}$ or $\mathrm{N}$ protein of SARS-CoV-2 and must be monoclonal to avoid cross reactions and improve sensitivity [54,55]. Also, these antibodies must be labeled with a fluorescent probe (Fluorescent label antibody, FLA) or chemiluminescent substances (Chemiluminescence Immunoassay Analyzer CLIA). After the incubation period, which takes between 10 to 20 minutes, the suspension is placed in the test cassette. Immunochromatography or lateral flow (LF) is the major platform for antigen detection, they sum $86.2 \%(56 / 65)$ of all antigen tests approved. This method is based on the sample flow through an assembly of membranes set on a test cassette and the separation of the target molecule by interaction with steady molecules attached to the membrane. When 
flowing through, the target viral antigen will be captured by antibodies held to the nitrocellulose membrane. A complex on the test line can be read visually or with suitable equipment $[49,53]$.

Tests for antigen detection stand out for allowing quickly diagnose of active infections, with testing times around $15 \mathrm{~min}$. Moreover, these tests have some advantages: non-specialists are need; do not require complex laboratory facilities; are more practical and cheaper than nucleic-acid-based tests [28]. On the other hands, they require a higher viral load, leading to loss of sensitivity [52]. In addition, viral antigens can be detected only when the individual is most infectious, within three to eleven days after symptoms onset [28]. There is a possibility of having false negative results due to reduced viral concentration if the samples are collected before or after this period [56]. In this sense, antigen tests are adequate for mass testing, especially for an initial screening of suspected cases. Patients positive for viral antigens do not need to undergo further tests, providing a quicker diagnose and reducing the search for nucleic acids assays. Patients who are negative for viral antigens, but present any COVID-19 symptoms or have and exposure history should undergo additional tests and be consider as suspected cases [38].

The antigen tests approved under the emergency status in Brazil showed sensitivity ranges from 60 to $100 \%$ and specificity ranges from 90 to $100 \%$. The tests with sensitivity varying from 90 to $94.99 \%$ correspond to $34.4 \%(22 / 64)$ and the ones with sensitivity varying from 95 to $100 \%$ represent $35.9 \%(23 / 64)$. A larger number of applications declared to have high sensitivity, which might indicate that the tests currently on the market have good analytical sensitivity. However, studies with commercial tests show that sensitivity may be different from the one provided by manufactures, which represents a higher risk of having a false test result [57]. For instance, a study carried out in England suggests that commercial tests should be independently validated[58].

When it comes to the tests target antigen, $72.3 \%$ of the tests approved by AVINSA do not specify the target protein. While $24.6 \%$ and $6.2 \%$ of the tests indicate that the targets are the $\mathrm{N}$ and $\mathrm{S}$ protein respectively. These data should be taken into consideration, especially because new SARS-CoV-2 variants can have differences in protein structure, which may affect the tests parameters [58].

\subsubsection{Antibody tests}

Antibodies are produced by the individual immune system during infection, and remain detectable in clinical samples even after long periods after the infection. Therefore, the presence of these molecules constitutes an indirect way to diagnose SARS-CoV-2 infections, whether they are ongoing or past ones. Antibody tests provide evidence about the serum prevalence of a population and allow identifying the regions with higher incidence of the disease [59]. Moreover, they are particularly important for identification of convalescent, asymptomatic and mild cases that might have been missed by other surveillance methods [60]. In addition, they permit the identification of the immune response patterns and also can be used to monitor the population seroconversion after vaccination [61].

The antibody tests have been used since the appearance of COVID-19, and are available on different platforms such as immunochromatography, ELISA, chemiluminescent immunoassay (CLIA) and fluorescent immunoassays (FIA). In fact, antibody tests have become so relevant during the pandemic that they correspond to $71.2 \%$ (356/500) of the tests approved in Brazil. The first ones are approved for use since March, 2020, computing 44 accepted applications. Over time, May was the month with most accepted applications (104). The testes come from 14 different countries, with the main origin in China with 58.3\% (203/500) of all granted applications, followed by Brazil, USA, and South Korea with 15.5\% (54), 6.9\% (24) and $5.2 \%$ (18) respectively (Figure $1 b$ ).

Samples for antibody tests consist mainly of blood, serum, plasma or saliva. The collection, transport and storage of samples do not represent any major challenges, because they are ordinary frequent procedures. If it is a point-of-care devise, sampling and testing should be performed right away. For others tests the specimen should be transported between $2-8^{\circ} \mathrm{C}$, and not frozen, until it reaches the testing facility.

The main challenge for antibodies assays is to test people at the right stage of infection. The production of antibodies occurs at different stages during the course of the infection and determines the possibility of the immunological test to detect its presence. The IgM isotype appears early, it can be detected after eight days after symptoms onset but they become undetectable in many cases on the seventh week. On the other hand, the detection of $\lg \mathrm{G}$ antibodies starts after two weeks, but persists for more than seven weeks [36,62]. $\lg A$ antibody tests are also available, but in smaller quantities. These antibodies start to be detectable around four to ten days, reaching a maximum peak on 16 to 20 days after symptoms onset $[63,64]$. IgA detection tests tend to be less sensitive, because its low concentration in the samples [65,66]. Most of the antibody tests approved by ANVISA have two targets 78.5\% (274/348), mainly IgM and IgG. 


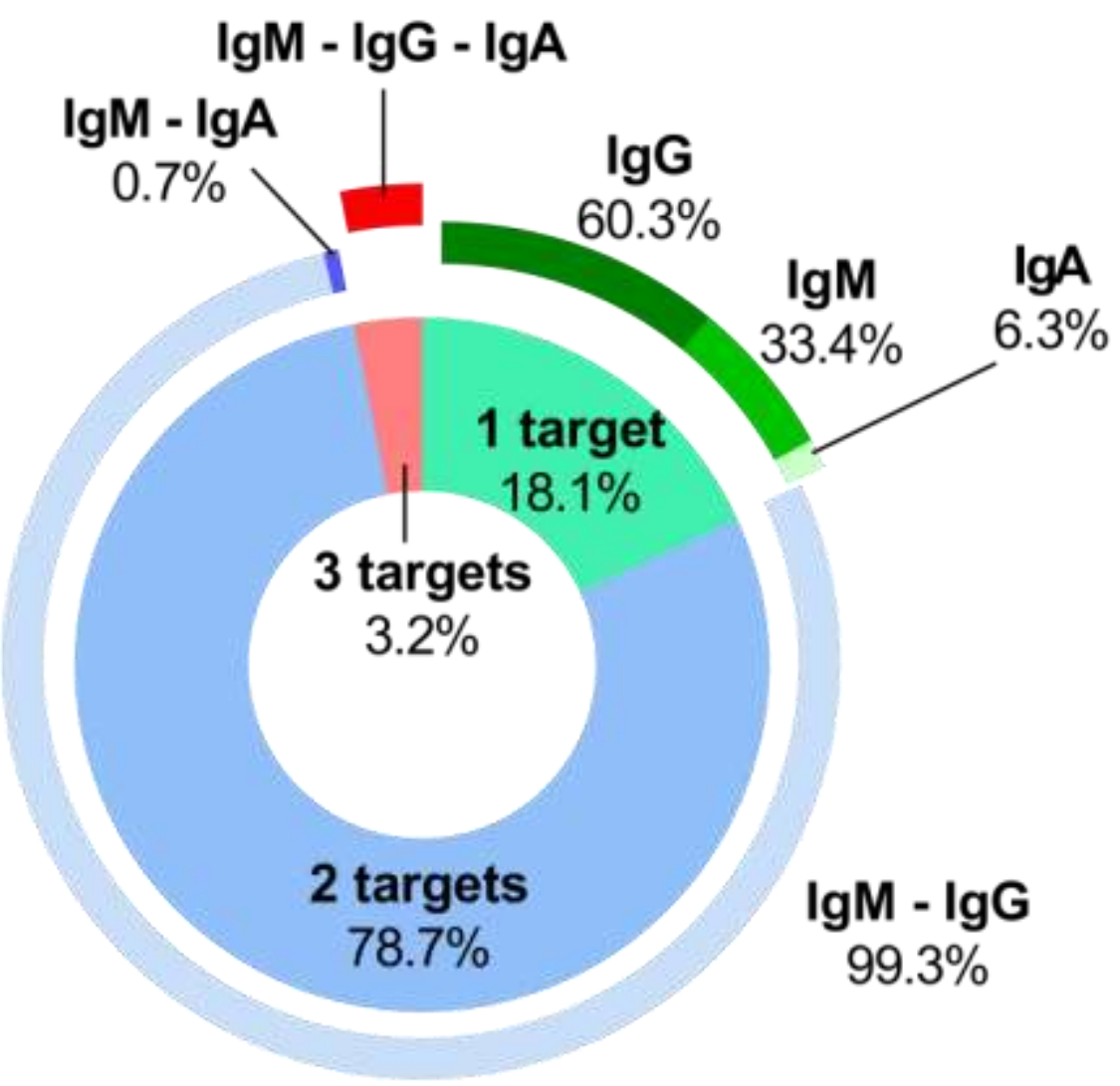

Figure 3. Target immunoglobulin for 348 antibody tests approved for use in Brazil. Data is provided by manufactures. Eight manufactures did not provide information about target immunoglobulin [27].

Antibody tests also depend on the selection of the best antigens and the ability of these antigens to bind to a specific SARS-CoV-2 antibodies [51]. The two main viral proteins used as antigens are $\mathrm{S}$ and $\mathrm{N}$ proteins. Both play an important role in the pathogenicity of the virus and are very antigenic [67]. The antigens can be used in the form of the complete protein, protein subunits and even peptides to fusion proteins combining different protein regions $[68,69]$. When selecting complete proteins as an antigen, it is possible to achieve greater antibody coverage, but there is the possibility of a cross-reaction with non-specific antibodies what decreases the sensitivity of the test. By selecting smaller regions of the protein as an antigen, it is possible to improve the sensitivity of the tests by selecting specific regions for the target virus. The use of peptides is aimed precisely at identifying the immune response directed to a single antigenic epitope, rather than the entire antigenic molecule. However, the sensitivity of the test can be reduced as many epitopes especially three-dimensional ones are lost [62].

Thus, the sensitivity of the assay is diverse and depends on the stage of infection, target antibody and the antigen. For this reason, it is essential to follow the instructions provided by manufacturers when applying these tests. In addition, patients with the severe cases of COVID-19 have a higher antibodies load compared to asymptomatic or mild cases. This can influence the dexterity of tests to provide a positive diagnosis and also to maintain this positive result for longer periods $[62,70]$.

\subsubsection{Immunochromatography}

Immunochromatography or lateral flow assays consists of a simple device that is used for point of care diagnostic. Immunochromatography tests targeting antibodies corresponds to $55.6 \%(278 / 500)$ of all applications accepted by AVINSA (Figure 1c). The principle of the technique is identical to antigen detection tests. The sample flows through four membranes: sample pad, conjugated pad, nitrocellulose membrane and absorbent pad. Antibodies anti-SARS-CoV-2 present in the sample bind to viral antigens conjugated with gold particles in the conjugated pad. Then, the complex formed is captured by secondary antibodies in the test line, which can be anti-human-IgM, anti-human-IgA or anti-human-IgG, depending on the target 
immunoglobulin for the test [32]. The assays can be set up to detect one, two or three isotypes in the same cassette. Tests targeting both IgM and IgG antibodies provide a better understanding on the stage of the disease and are recommended for screening suspected COVID-19 cases [32]. The test's sensitivity and specificity provided by manufactures ranges from 55 to $100 \%$ and 80 to $100 \%$ respectively (Table 1). Most of the tests $86.0 \%$ (239/278) have high specificity, ranging from 95 to $100 \%$. However, sensitivity has larger variance.

Table 1. Parameters of lateral flow tests approved by ANVISA for use in Brazil. The sensitivity and specificity were provided by manufactures. Eight manufacturers did not provide information regards to sensitivity or specificity [27].

\begin{tabular}{c|c|c|c|c|c|c|c|c|c|c|c}
\hline \multirow{2}{*}{ Specificity } & \multicolumn{10}{|c|}{ Sensitivity } & \multicolumn{2}{c}{ Total } \\
& {$[55-60\rangle$} & {$[60-65\rangle$} & {$[65-70\rangle$} & {$[70-75\rangle$} & {$[75-80\rangle$} & {$[80-85\rangle$} & {$[85-90\rangle$} & {$[90-95\rangle$} & {$[95-100]$} & $\%$ \\
\hline \multirow{2}{*}{$80-85$} & 0 & 0 & 0 & 0 & 0 & 0 & 1 & 0 & 0 & 1 \\
& 0.0 & 0.0 & 0.0 & 0.0 & 0.0 & 0.0 & 0.4 & 0.0 & 0.0 & 0.4 \\
\hline$[85-90\rangle$ & 0 & 0 & 0 & 0 & 0 & 0 & 1 & 0 & 0 & 1 \\
& 0.0 & 0.0 & 0.0 & 0.0 & 0.0 & 0.0 & 0.4 & 0.0 & 0.0 & 0.4 \\
\hline$[90-95\rangle$ & 0 & 0 & 0 & 0 & 2 & 7 & 3 & 5 & 12 & 29 \\
& 0.0 & 0.0 & 0.0 & 0.0 & 0.7 & 2.6 & 1.1 & 1.9 & 4.4 & 10.7 \\
\hline $59-100]$ & 6 & 1 & 6 & 8 & 24 & 27 & 53 & 53 & 61 & 239 \\
& 2.2 & 0.4 & 2.2 & 3.0 & 8.9 & 10.0 & 19.6 & 19.6 & 22.6 & 88.5 \\
\hline \multirow{2}{*}{ Total } & 6 & 1 & 6 & 8 & 26 & 34 & 58 & 58 & 73 & 270 \\
& 2.2 & 0.4 & 2.2 & 3.0 & 9.6 & 12.6 & 21.5 & 21.5 & 27.0 & 100.0 \\
\hline
\end{tabular}

\subsubsection{Enzyme linked immunosorbent assay (ELISA)}

ELISA tests can be performed on different platforms, the indirect ELISA being the main format used for diagnosing COVID-19. In this method, the surfaces of high-affinity microplates are coated with viral antigen, which captures specific antibodies against the virus. Subsequently, a secondary conjugated antibody is responsible for detecting the complex formed. This technique is well established, and it is relatively simple. It does not require specialized technical staff and can be automatized. With that, ELISA tests are excellent for large-scale testing [71].

Of the total number of applications accepted by ANVISA, ELISA corresponds to $7.6 \%(38 / 500)$ (Figure 1c). The sensitivity and specificity provided by manufactures ranges from 55 to $100 \%$ and 85 to $100 \%$ respectively (Table 2). Most of the tests $(21 / 31(67.7 \%))$ have high sensitivity, from 95 to $100 \%$. In addition, most of the tests $87.1 \%(27 / 31)$ have high specificity, from 95 to $100 \%$. The data shows that there is a huge discrepancy between ELISA tests available. However, must of the test showed high sensitivity and specificity.

Table 2. Sensibility and specificity of ELISA tests approved by ANVISA for use in Brazil. The sensitivity and specificity were provided by manufactures. Two tests consists of neutralizing antibodies tests and are not included in this table. Five manufactures did not provide information regards sensitivity or specificity [27].

\begin{tabular}{|c|c|c|c|c|c|c|c|}
\hline \multirow{2}{*}{ Specificity } & \multicolumn{6}{|c|}{ Sensibility } & \multirow{2}{*}{$\begin{array}{c}\text { Total } \\
\%\end{array}$} \\
\hline & {$[55-60\rangle$} & {$[65-70\rangle$} & {$[75-80\rangle$} & {$[85-90\rangle$} & {$[90-95\rangle$} & [95-100] & \\
\hline \multirow{2}{*}{$85-90$} & 0 & 0 & 0 & 0 & 0 & 2 & 2 \\
\hline & 0.00 & 0.00 & 0.00 & 0.00 & 0.00 & 6.45 & 6.45 \\
\hline \multirow{2}{*}{$90-95$} & 0 & 0 & 0 & 0 & 1 & 1 & 2 \\
\hline & 0.00 & 0.00 & 0.00 & 0.00 & 3.23 & 3.23 & 6.45 \\
\hline \multirow{2}{*}{ [95-100] } & 2 & 1 & 2 & 2 & 2 & 18 & 27 \\
\hline & 6.45 & 3.23 & 6.45 & 6.45 & 6.45 & 58.06 & 87.10 \\
\hline \multirow{2}{*}{ Total } & 2 & 1 & 2 & 2 & 3 & 21 & 31 \\
\hline & 6.45 & 3.23 & 6.45 & 6.45 & 9.68 & 67.74 & 100.00 \\
\hline
\end{tabular}

There are two additional diagnostic methodologies that are used to a lesser extent than previously described. CLIA being a variation of the ELISA methodology by changing the ELISA plate support to beads, 
and the use of chemiluminescent substances. FIA is the variation of immunochromatographic methodology using secondary antibody conjugated to a fluorescent probe, Corresponding to $5.4 \%(27 / 500)$ for CLIA and $4 \%(20 / 500)$ for FIA of the total number of applications granted (Figure 1c).

\subsection{Considerations on diagnostic tests}

The data explored here showed the breadth and diversity of tests approved in Brazil. Although several of these tests are approved for emergency use, the application of one or more tests in the population favors the real understanding of epidemiology in the country.

In the next session we explore the epidemiological data and the application of tests in Brazil by federative unit.

\section{FREQUENCY OF CASES AND SAMPLES TESTING IN BRAZIL}

Until February 8, 2021 the number of COVID-19 cases in Brazil was 9,550,301 and the total number of deaths was 232,248 , being the third country with the highest number of cases and the second in number of deaths, behind only of the USA (WHO, 2021). Brazil has 27 federative units, distributed in 26 states and the Federal District, which allows for demographic, economic and social diversity in the country, associated with its great extension leads to a variation in the number of the disease cases per 100,000 populations (Figure 4). However, this variation is perhaps associated with the quantity and quality of testing performed on the population. Since as showed above, the actual endorsement of COVID-19 diagnosis tests in Brazil became less rigorous what can allow the commercialization of tests that may not be as effective. Although the states of the five regions of Brazil (North, South, Northeast, Southeast and Midwest) have similarities in terms of socio-cultural aspects, the data on the number of cases and samples tested for COVID-19 is variable within these regions (Figure $4 a$ and $4 b$ ).

Some of the federative units that tested the greatest number of samples also showed the greatest number of cases, such as: Roraima (RR), Distrito Federal (DF), Santa Catarina (SC), Espírito Santo (ES), Rondônia (RO), Amazonas (AM) and Tocantins (TO). While some of the federative units that tested less samples also had a smaller number of cases, such as: Maranhão (MA), Alagoas (AL), Pará (PA), Pernambuco (PE) and Rio de Janeiro (RJ) (Figure 4a and 4b).

Accurate diagnosis of COVID-19 can help clinical management, inform allocation of individual isolation, contact tracing and treatment and decrease transmission [72]. In this sense, the immunological tests to detect antibodies could be the most appropriated to get epidemiological information [28].

Here, we analysed data from Federal University of Viçosa (https://covid19br.wcota.me/). The data showed that some federative units of Brazil have shown high ratio between the cases per samples tested (Figure 4c), such as:

1- $\quad$ Amazonas (AM), Alagoas (AL), Sergipe (SE), Goiás (GO), Rio Grande do Sul (RS), Amapá (AM), Maranhão (MA) and Santa Cartarina (SC) above of $40 \%$.

2- $\quad$ Federative Units such as: Federal District (DF), Roraima (RR), Pernambuco (PE), Espírito Santo (ES), Paraíba (PB), Paraná (PR), Tocantins (TO), Bahia (BA) and Mato Grosso do Sul (MS) displayed a percentage of positive cases between 30 and $40 \%$ of the tested samples.

3- $\quad$ The states of Ceará (CE), Mato Grosso (MT), Pará (PA), Rio Grande do Norte (RN), Minas Gerais (MG), Piaui (PI), Rondônia (RO), Rio de Janeiro (RJ) and São Paulo (SP) showed number of cases between 20 and $30 \%$ of the tested samples. A frequency of positive results of $10 \%$ or less indicates that the region comprises the actual number of people infected [73].

4- The only federative unit that presented a percentage of testing lower than $10 \%$ was Acre (AC), in which only $0.39 \%$ of the tested samples were positive what suggests an appropriated number of tests for decision making.

5- In other federative units of Brazil this frequency was higher than $20 \%$ what suggests that the data are underreported in almost all Brazilian federative units. It is important to point out that until the date evaluated here, it was ensured that the Amazonas state (AM) displayed a higher percentage of number of cases per tested samples (Figure 4c). 
At the beginning of 2021, a new variant of the virus was isolated, which suggests that this high number of cases may be related to this new variant, which appears to be more transmissible and virulent [74].

All of these data lead us to believe that the real number of positive cases in other states is much higher, especially those that test a small portion of its population.

Early diagnosis helps to measure and control the spread of the virus, allowing the isolation of infected people. Such measures being applied safely and effectively greatly reduces the number of cases and deaths.

a

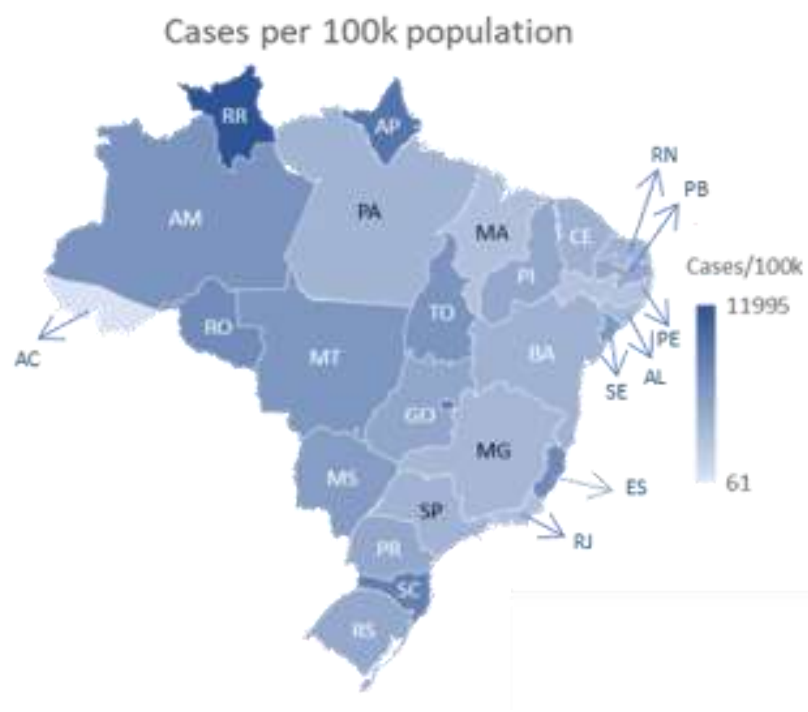

C b Samples tested per 100k population

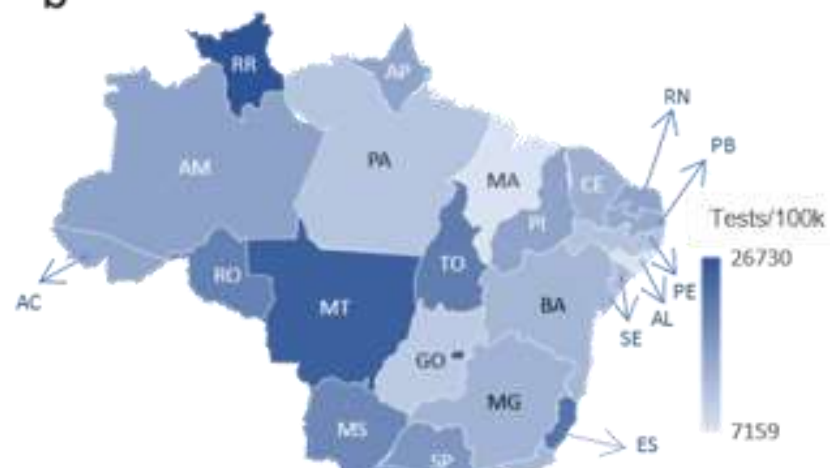

MS Pat MG $>$ ES 7159
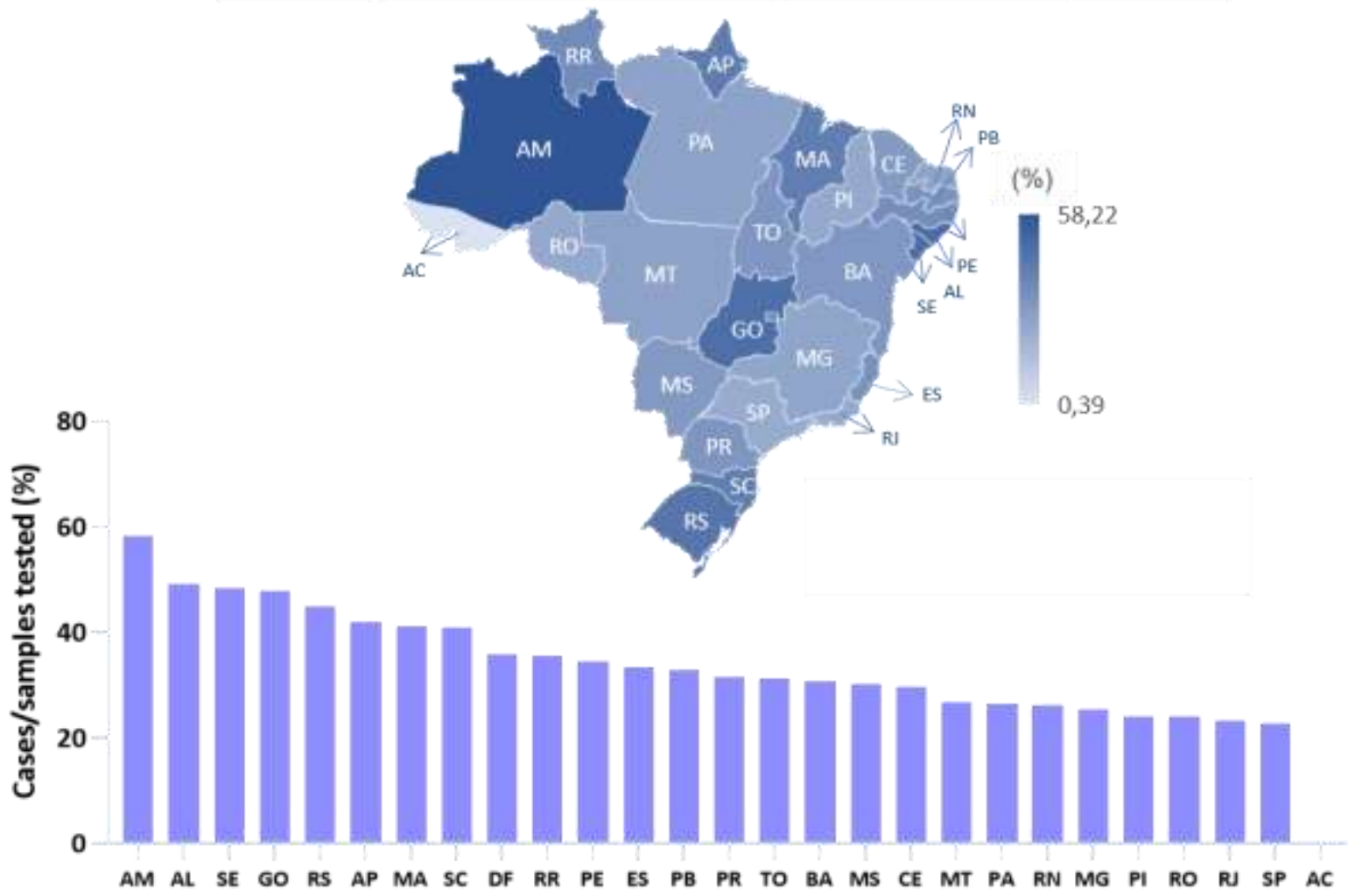

Federatives Units of Brazil

Figure 4. Frequency of cases (a), samples tested (b) and the ratio of cases per sample tested (c) in the federative units of Brazil since the beginning of COVID-19 pandemic until $8^{\text {th }}$ February 2021. 


\section{CONCLUSION}

In summary, this review showed that currently immunological tests account for $84.2 \%$ of the tests approved from the Brazilian regulatory agency (ANVISA) and $15.8 \%$ are nucleic-acid-based tests. Of the immunological tests, $71.2 \%$ are antibody tests and $13 \%$ are antigen tests. For molecular tests, $57.3 \%$ use two targets to confirm positive tests and $24 \%$ use three targets. The number of tests carried out in the different federal units of Brazil is still low once the percentage of cases in the samples tested is elevated. Eight states showed $40 \%$ of positive cases in tested samples, while 18 states displayed between 20 and $40 \%$. More than $80 \%$ of the approved products for COVID-19 diagnosis are imported from other countries. In this sense, Brazil is dependent on external technology to respond to pandemics, epidemics and endemics disease what indicate its technological park is in development. One piece of this information is "Brazil needs to improve its biotechnological scheme to solve further diseases outbreaks".

Funding: This research was funded by CAPES, grant number 88881.505280/2020-01, Plataforma biotecnológica de identificação e produção de antígenos para diagnósticos de doenças emergentes aplicada na prevenção e combate a surtos, endemias, epidemias e pandemias

Acknowledgments: The authors would like to acknowledge the financial support from CAPES grant number 88881.505280/2020-01.

Conflicts of Interest: The authors declare no conflict of interest.

\section{REFERENCES}

1. Zhou P, Yang X Lou, Wang XG, Hu B, Zhang L, Zhang W, et al. A pneumonia outbreak associated with a new coronavirus of probable bat origin. Nature. 2020 Mar;579(7798):270-3.

2. Tang X, Wu C, Li X, Song Y, Yao X, Wu X, et al. On the origin and continuing evolution of SARS-CoV-2. Natl Sci Rev. 2020 Jun;7(6):1012-23.

3. Cucinotta D, Vanelli M. WHO declares COVID-19 a pandemic. Vol. 91, Acta Biomed. Mattioli 1885; 2020. p. 15760.

4. Worldometer [Internet]. Coronavirus Update (Live): 108,512,602 cases and 2,384,360 deaths from COVID-19 virus pandemic; [cited $2021 \mathrm{Feb}$ 08]. Available from: https://www.worldometers.info/coronavirus/

5. Nicola M, Alsafi Z, Sohrabi C, Kerwan A, Al-Jabir A, losifidis C, et al. The socio-economic implications of the coronavirus pandemic (COVID-19): A review. Vol. 78, Int J Surg.. Elsevier Ltd; 2020. p. 185-93.

6. Gorbalenya AE, Baker SC, Baric RS, de Groot RJ, Drosten C, Gulyaeva AA, et al. The species severe acute respiratory syndrome-related coronavirus: classifying 2019-nCoV and naming it SARS-CoV-2. Vol. 5, Nat Microbiol. Nature Research; 2020. p. 536-44.

7. Su S, Wong G, Shi W, Liu J, Lai ACK, Zhou J, et al. Epidemiology, genetic recombination, and pathogenesis of coronaviruses. Vol. 24, Trends Microbiol. Elsevier Ltd; 2016. p. 490-502.

8. Ye ZW, Yuan S, Yuen KS, Fung SY, Chan CP, Jin DY. Zoonotic origins of human coronaviruses [Internet]. Vol. 16, Int J Biol Sci. Ivyspring International Publisher; 2020 [cited 2021 Mar 10]. p. 1686-97. Available from: /pmc/articles/PMC7098031/

9. Wong G, Bi YH, Wang QH, Chen XW, Zhang ZG, Yao YG. Zoonotic origins of human coronavirus 2019 (HCoV-19 / SARS-CoV-2): Why is this work important? Zool Res. 2020;41(3):213-9.

10. Harrison AG, Lin T, Wang P. Mechanisms of SARS-CoV-2 transmission and pathogenesis. Vol. 41, Trends Immunol. Elsevier Ltd; 2020. p. 1100-15.

11. Yan R, Zhang Y, Li Y, Xia L, Guo Y, Zhou Q. Structural basis for the recognition of SARS-CoV-2 by full-length human ACE2. Science. 2020 Mar;367(6485):1444-8.

12. Hwang SS, Lim J, Yu Z, Kong P, Sefik E, Xu H, et al. MRNA destabilization by BTG1 and BTG2 maintains T cell quiescence. Science. 2020 Mar;367(6483):1255-60.

13. Ziegler CGK, Allon SJ, Nyquist SK, Mbano IM, Miao VN, Tzouanas CN, et al. SARS-CoV-2 receptor ACE2 is an interferon-stimulated gene in human airway epithelial cells and is detected in specific cell ubsets across Tissues. Cell. 2020 May;181(5):1016-1035.e19.

14. Li Q, Wu J, Nie J, Zhang L, Hao H, Liu S, et al. The impact of mutations in sars-cov-2 spike on viral infectivity and antigenicity. Cell. 2020 Sep;182(5):1284-1294.e9.

15. Korber B, Fischer WM, Gnanakaran S, Yoon H, Theiler J, Abfalterer W, et al. Tracking changes in SARS-CoV-2 spike: evidence that D614G increases infectivity of the COVID-19 virus. Cell. 2020 Aug;182(4):812-827.e19.

16. Mukhra R, Krishan K, Kanchan T. Possible modes of transmission of novel coronavirus SARS-CoV-2: a review. Vol. 91, Acta Biomed. Mattioli 1885; 2020. p. 1-11.

17. Li Q, Guan X, Wu P, Wang X, Zhou L, Tong Y, et al. Early transmission dynamics in Wuhan, China, of novel coronavirus-infected pneumonia. N Engl J Med. 2020 Mar;382(13):1199-207.

18. Novelli G, Biancolella M, Mehrian-Shai R, Erickson C, Godri Pollitt KJ, Vasiliou V, et al. COVID-19 update: the first 6 months of the pandemic. Vol. 14, Hum Genomics. BioMed Central Ltd; 2020. 
19. Van Der Made Cl, Simons A, Schuurs-Hoeijmakers J, Van Den Heuvel G, Mantere T, Kersten S, et al. Presence of genetic variants among young men with severe COVID-19. JAMA - J Am Med Assoc. 2020 Aug;324(7):663-73.

20. Chen N, Zhou M, Dong X, Qu J, Gong F, Han Y, et al. Epidemiological and clinical characteristics of 99 cases of 2019 novel coronavirus pneumonia in Wuhan, China: a descriptive study. Lancet. 2020 Feb;395(10223):507-13.

21. Huang C, Wang Y, Li X, Ren L, Zhao J, Hu Y, et al. Clinical features of patients infected with 2019 novel coronavirus in Wuhan, China. Lancet. 2020 Feb;395(10223):497-506.

22. Chan JFW, Yuan S, Kok KH, To KKW, Chu H, Yang J, et al. A familial cluster of pneumonia associated with the 2019 novel coronavirus indicating person-to-person transmission: a study of a family cluster. Lancet. 2020 Feb;395(10223):514-23.

23. Wang D, Hu B, Hu C, Zhu F, Liu X, Zhang J, et al. Clinical characteristics of 138 hospitalized patients with 2019 novel coronavirus-infected pneumonia in Wuhan, China. JAMA - J Am Med Assoc. 2020 Mar;323(11):1061-9.

24. Diário Oficial da União, Imprensa Nacional, Resolução RDC No 348 (Mar 17, 2020).

25. Ministério da Saúde (BR), Acurácia dos testes diagnósticos registrados na ANVISA para a COVID-19. Brasília: Ministério da Saúde, 2020 May. 35 p.

26. Petramale CA. Testes diagnósticos para a identificação do vírus SARS-CoV-2 e para o diagnóstico da COVID-19; 2020 May.

27. Ministério da Saúde (BR), Agência Nacional de Vigilância Sanitária [Internet]. Covid-19: painel de produtos para diagnóstico. Brasília: Ministério da Saúde, 2021 [cited 2021 Feb 8]. Available from: https://www.gov.br/anvisa/ptbr/assuntos/noticias-anvisa/2020/covid-19-painel-de-produtos-para-diagnostico

28. Guglielmi G. Rapid coronavirus tests: a guide for the perplexed. Nature [Internet]. 2021 [cited 2021 Feb 21];590(7845):202-5. Available from: http://www.ncbi.nlm.nih.gov/pubmed/33564189

29. Rosa MFF, da Silva EN, Pacheco C, Diógenes MVP, Millett C, Gadelha CAG, et al. Direct from the COVID-19 crisis: research and innovation sparks in Brazil. Vol. 19, Health Res Pol Syst. BioMed Central Ltd; 2021.

30. Asselah T, Durantel D, Pasmant E, Lau G, Schinazi RF. COVID-19: Discovery, diagnostics and drug development. Vol. 74, J Hepatol. Elsevier B.V.; 2021. p. 168-84.

31. Laureano AFS, Riboldi M. The different tests for the diagnosis of covid-19-a review in Brazil so far. Vol. 24, JBRA Assist Reprod. Sociedade Brasileira de Reproducao Assistida; 2020. p. 340-6.

32. Li Z, Yi Y, Luo X, Xiong N, Liu Y, Li S, et al. Development and clinical application of a rapid lgM-lgG combined antibody test for SARS-CoV-2 infection diagnosis. J Med Virol. 2020 Sep 1;92(9):1518-24.

33. Corman VM, Landt O, Kaiser M, Molenkamp R, Meijer A, Chu DKW, et al. Detection of 2019 novel coronavirus (2019-nCoV) by real-time RT-PCR. Euro Surveill. 2020 Jan 23;25(3).

34. Jung Y, Park GS, Moon JH, Ku K, Beak SH, Lee CS, et al. Comparative analysis of primer-probe sets for RT-qPCR of COVID-19 causative virus (SARS-CoV-2). ACS Infect Dis. 2020;6(9):2513-23.

35. Vijgen L, Moës E, Keyaerts E, Li S, Van Ranst M. A pancoronavirus RT-PCR assay for detection of all known coronaviruses. Methods Mol Biol. 2008;454:3-12.

36. Sethuraman N, Jeremiah SS, Ryo A. Interpreting diagnostic tests for SARS-CoV-2 [Internet]. Vol. 323, JAMA. American Medical Association; 2020 [cited 2021 Feb 22]. p. 2249-51. Available from: https://jamanetwork.com/

37. Corman VM, Landt O, Kaiser M, Molenkamp R, Meijer A, Chu DK, et al. Detection of 2019 novel coronavirus (2019nCoV) by real-time RT-PCR. Euro Surveill. 2020 Jan;25(3).

38. Center of Desease Control CDC. Interim guidance for antigen testing for SARS-CoV-2. [cited 2021 Feb 22]. Available from: https://www.cdc.gov/coronavirus/2019-ncov/lab/resources/antigen-tests-guidelines.html\#table1

39. Chu DKW, Pan Y, Cheng SMS, Hui KPY, Krishnan P, Liu Y, et al. Molecular diagnosis of a novel coronavirus (2019-nCoV) causing an outbreak of pneumonia. Clin Chem. 2020;66(4):549-55.

40. Boni MF, Lemey P, Jiang X, Lam TTY, Perry BW, Castoe TA, et al. Evolutionary origins of the SARS-CoV-2 sarbecovirus lineage responsible for the COVID-19 pandemic. Nat Microbiol [Internet]. 2020;5(11):1408-17. Available from: http://dx.doi.org/10.1038/s41564-020-0771-4

41. Zhu N, Zhang D, Wang W, Li X, Yang B, Song J, et al. A novel coronavirus from patients with pneumonia in China, 2019. N Engl J Med. 2020;382(8):727-33.

42. Sahajpal NS, Mondal AK, Njau A, Ananth S, Jones K, Ahluwalia PK, et al. Proposal of RT-PCR-based mass population screening for severe acute respiratory syndrome coronavirus 2 (coronavirus disease 2019). J Mol Diagn. 2020;22(10):1294-9.

43. Garg J, Singh V, Pandey P, Verma A, Sen M, Das A, et al. Evaluation of sample pooling for diagnosis of COVID19 by real time-PCR: A resource-saving combat strategy. J Med Virol. 2021;93(3):1526-31.

44. Abdalhamid B, Bilder CR, McCutchen EL, Hinrichs SH, Koepsell SA, Iwen PC. Assessment of specimen pooling to conserve SARS CoV-2 testing resources. Am J Clin Pathol. 2020;153(6):715-8.

46. Rhee C, Kanjilal S, Baker M, Klompas M. Duration of severe acute respiratory syndrome coronavirus 2 (SARSCoV-2) infectivity: when is it safe to discontinue ssolation? Clin Infect Dis. 2020;2:23-8.

47. Santarpia JL, Rivera DN, Herrera VL, Morwitzer MJ, Creager HM, Santarpia GW, et al. Aerosol and surface contamination of SARS-CoV-2 observed in quarantine and isolation care. Sci Rep [Internet]. 2020;10(1):12732. Available from: http://www.nature.com/articles/s41598-020-69286-3 
48. Rimoldi SG, Stefani F, Gigantiello A, Polesello S, Comandatore F, Mileto D, et al. Presence and infectivity of SARSCoV-2 virus in wastewaters and rivers. Sci Total Environ [Internet]. 2020;744:140911. Available from: https://doi.org/10.1016/j.scitotenv.2020.140911

49. Premraj A, Aleyas AG, Nautiyal B, Rasool TJ. Nucleic acid and immunological diagnostics for SARS-CoV-2: processes, platforms and pitfalls. Vol. 10, Diagnostics. 2020. $866 \mathrm{p}$.

50. World Health Organization, Mission China Joint. Report of the WHO-China joint mission on coronavirus disease 2019 (COVID-19). WHO-China Jt Mission Coronavirus Dis 2019 [Internet]. 2020;2019(February):16-24. Available from: https://www.who.int/docs/default-source/coronaviruse/who-china-joint-mission-on-covid-19-final-report.pdf

51. Kilic T, Weissleder R, Lee H. Molecular and immunological diagnostic tests of COVID-19: current status and challenges. Vol. 23, iScience. Elsevier Inc.; 2020. p. 101406.

52. Yamayoshi S, Sakai-Tagawa Y, Koga M, Akasaka O, Nakachi I, Koh H, et al. Comparison of rapid antigen tests for COVID-19. Viruses [Internet]. 2020 Dec 10 [cited 2021 Feb 24];12(12):1420. Available from: https://www.mdpi.com/1999-4915/12/12/1420

53. Darwish IA. Immunoassay methods and their applications in pharmaceutical analysis: basic methodology and recent advances. Int J Biomed Sci. 2006 Sep;2(3):217-35.

54. Sheridan C. Fast, portable tests come online to curb coronavirus pandemic. Vol. 38, Nat biotechnol. NLM (Medline); 2020. p. 515-8.

55. Diao B, Wen K, Chen J, Liu Y, Yuan Z, Han C, et al. Diagnosis of acute respiratory syndrome coronavirus 2 infection by detection of nucleocapsid protein running title: Diagnosis of COVID-19 by $\mathrm{N}$ antigen detection. medRxiv [Internet]. 2020 Mar 13 [cited 2021 Feb 19];2020.03.07.20032524. Available from: https://doi.org/10.1101/2020.03.07.20032524

56. Crozier A, Rajan S, Buchan I, McKee M. Put to the test: use of rapid testing technologies for covid-19. BMJ. 2021 Feb;n208.

57. Torjesen I. Covid-19: How the UK is using lateral flow tests in the pandemic. BMJ. 2021;372:1-3.

58. TEAM LFO, Peto T. COVID-19: Rapid Antigen detection for SARS-CoV-2 by lateral flow assay: a national systematic evaluation for mass-testing. medRxiv. 2021;

59. Jia Z, Lu Z. The important role of serology for COVID-19 control. Lancet Infect Dis [Internet]. 2020 [cited 2021 Feb 26];20:758-9. Available from: https://doi.org/10.1016/S1473-3099

60. Yong SEF, Anderson DE, Wei WE, Pang J, Chia WN, Tan CW, et al. Connecting clusters of COVID-19: an epidemiological and serological investigation. Lancet Infect Dis. 2020 Jul 1;20(7):809-15.

61. Krammer F, Simon V. Serology assays to manage COVID-19. Vol. 368, Science. American Association for the Advancement of Science; 2020. p. 1060-1.

62. Serrano MM, Rodríguez DN, Palop NT, Arenas RO, Córdoba MM, Mochón MDO, et al. Comparison of commercial lateral flow immunoassays and ELISA for SARS-CoV-2 antibody detection. J Clin Virol. 2020 Aug 1;129:104529.

63. Ma H, Zeng W, He H, Zhao D, Jiang D, Zhou P, et al. Serum IgA, IgM, and IgG responses in COVID-19. Cell Mol Immunol. $2020 \mathrm{Jul} ; 17(7): 773-5$.

64. Gudbjartsson DF, Norddahl GL, Melsted P, Gunnarsdottir K, Holm H, Eythorsson E, et al. Humoral Immune Response to SARS-CoV-2 in Iceland. N Engl J Med. 2020 Oct;383(18):1724-34.

65. Jääskeläinen $A J$, Kekäläinen $E$, Kallio-Kokko $H$, Mannonen L, Kortela $E$, Vapalahti $O$, et al. Evaluation of commercial and automated SARS-CoV-2 IgG and IgA ELISAs using coronavirus disease (COVID-19) patient samples. Euro surveill [Internet]. 2020 May 7 [cited 2021 Feb 22];25(18):2000603. Available from: https://www.eurosurveillance.org/content/10.2807/1560-7917.ES.2020.25.18.2000603

66. Lou B, Li TD, Zheng SF, Su YY, Li ZY, Liu W, et al. Serology characteristics of SARS-CoV-2 infection since the exposure and post symptoms onset. medRxiv. medRxiv; 2020.

67. Okba NMA, Müller MA, Li W, Wang C, Geurtsvankessel CH, Corman VM, et al. Severe acute respiratory syndrome coronavirus 2-specific antibody responses in coronavirus disease patients. Emerg Infect Dis [Internet]. $2020 \mathrm{Jul} 1$ [cited 2021 Feb 23];26(7):1478-88. Available from: https://doi.org/10.1101/2020.03.11.987958.

68. Chen Y, Tong X, Li Y, Gu B, Yan J, Liu Y, et al. A comprehensive, longitudinal analysis of humoral responses specific to four recombinant antigens of SARS-CoV-2 in severe and non-severe COVID-19 patients. Fouchier RAM, editor. PLOS Pathog [Internet]. 2020 Sep 10 [cited 2021 Feb 23];16(9):e1008796. Available from: https://dx.plos.org/10.1371/journal.ppat.1008796.

69. Cai X, Chen J, li Hu J-, Long $Q$, Deng $H$, Liu P, et al. A peptide-based magnetic chemiluminescence enzyme immunoassay for serological diagnosis of coronavirus disease 2019. J Infect Dis [Internet]. 2020 Jun 29 [cited 2021 Feb 23];222(2):189-93. Available from: https://academic.oup.com/jid/article/222/2/189/5831993.

70. Du Z, Zhu F, Guo F, Yang B, Wang T. Detection of antibodies against SARS-CoV-2 in patients with COVID-19. J Med Virol [Internet]. 2020 Oct 10 [cited 2021 Feb 23];92(10):1735-8. Available from: https://onlinelibrary.wiley.com/doi/10.1002/jmv.25820.

71. Carter LJ, Garner L V., Smoot JW, Li Y, Zhou Q, Saveson CJ, et al. Assay techniques and test development for COVID-19 diagnosis. ACS Cent Sci [Internet]. 2020 May 27 [cited 2021 Feb 26];6(5):591-605. Available from: https://dx.doi.org/10.1021/acscentsci.0c00501. 
72. Aziz AB, Raqib R, Khan WA, Rahman M, Haque R, Alam M, et al. Integrated control of COVID-19 in resource-poor countries. Int J Infect Dis. 2020; 101: 98-101.

73. Lisboa Bastos M, Tavaziva G, Abidi SK, Campbell JR, Haraoui L-P, Johnston JC, et al. Diagnostic accuracy of serological tests for covid-19: systematic review and meta-analysis. BMJ [Internet]. 2020;370:2516. Available from: https://connect.medrxiv.org/relate/content/181.

74. Naveca F, da Costa C, Nascimento V, Souza V, Corado A, Nascimento, Fernanda-Costa Á, et al. SARS-CoV-2 reinfection by the new variant of concern (VOC) P.1 in Amazonas, Brazil. VirologicalOrg. 2021.

cC (1) (8) 2021 by the authors. Submitted for possible open access publication under the terms and (c) conditions of the Creative Commons Attribution (CC BY NC) license (https://creativecommons.org/licenses/by-nc/4.0/). 